\title{
Krishibhagya Scheme: An Impact Study for Improvement of Livelihood of the Farmers in Hyderabad-Karnataka Region, India
}

\author{
Moulasab*, S.K. Meti, and M.B. Ashoka \\ University of Agricultural Sciences, Raichur - 584 104, Karnataka, India \\ *Corresponding author
}

\section{A B S T R A C T}

Keywords

Beneficiaries and non-beneficiaries, Farm pond, Income, Krishibhagya, Impact, Polyhouse and Shade net

Article Info

Accepted:

06 June 2018

Available Online:

10 July 2018
The present study was conducted to know the impact of Krishibhagya scheme on beneficiaries of Hyderabad-Karnataka region during the year 2017-18. The present study was conducted in six districts namely Bidar, Kalaburagi, Yadgir, Raichur, Koppal and Ballari coming under the jurisdiction of University of Agricultural Sciences Raichur, Karnataka. From each district 5 Krishibhagya beneficiaries (including both Farm pond and Polyhouse) and 5 non beneficiaries were selected randomly following simple random sampling technique. The data was collected from the respondents using structured interview schedule prepared for the purpose. The collected data was analysed using appropriate statistical tools. The results of the study revealed that, there is a 17 to 53 per cent increase in average yield of important crops due to implementation of Farm pond under Krishibhagya scheme, Govt. of Karnataka and increase in income of the beneficiary farmers from Rs. 8800 to Rs. $43848 \mathrm{ac}^{-1}$. There is a 31 to 58 per cent increase in yield of important horticulture crops due to polyhouse/shade net in Krishibhagya scheme. Hence there is a need to continue and implement the krishibhagya scheme to other areas. There is a need to educate the farmers to go for cultivation of high value commercial crops instead of low value crops as the irrigation facility is available. Administrators and policy makers should think of adding more components to the scheme in order to improve the socioeconomic status of the farmers and for sustainable agriculture development.

\section{Introduction}

Agriculture plays a vital role in the economy of the country. It is the means of livelihood for more than 70 percent of the population in the country. Good and efficient performance of this sector is vital for food security, employment, eradicating hunger, alleviating poverty, controlling inflation, promoting economic growth and stabilizing economies. Agriculture-led development is fundamental to cutting hunger and reducing poverty in the country.

India is a rural country wherein more than 65 per cent of the people reside in villages. The socio-economic status of more than 60 percent of the villages in the country is very poor. 
Many developmental programmes were introduced after the independence by the central and state governments for upliftment of socio-economic status of the rural people. More than 65 per cent of the agricultural land in the state is under rainfed farming which contributes about 55 per cent of food grain and 75 percent of the oilseed production. There is a need to improve the socio-economic status of the farmers in these areas by conserving natural resources like soil and water. In order to improve the living standard of farmers in rainfed areas, the Government of Karnataka introduced "Krishibhagya" scheme during 2014.

Krishibhagya is a flagship programme of the Government of Karnataka aimed at sustainable development of the farming community in the rainfed areas through conservation and use of rain water through rain water harvesting, adoption of dairy activities and effective natural resource management.

Under Krishibhagya scheme, the government is supporting the farmers to construct a farm pond with polythene lining, install pump set with sprinkler irrigation system. This intervention helps farmers to harvest surplus rainwater and use it as lifesaving irrigation to sustain the production and thereby it is possible to enhance the yield by 30 per cent. This intervention can potentially help farmers to stand on their own feet.

When the government spend lot of money on such schemes, it is essential to know the impact of these programmes on stakeholders and also get the feedback on any modification or improvement needed in programmes.

Hence, the present study $\mathrm{n}$ impact of Krishi Bhagya Scheme on beneficiary farmers was initiated with the following objectives,

1. To know the impact of farm pond and poly house on yield of important crops

2. To know the impact of farm pond and poly house on income of beneficiaries

\section{Materials and Methods}

The present study was conducted in six districts namely Bidar, Kalaburagi, Yadgir, Raichur, Koppal and Ballari coming under the jurisdiction of University of Agricultural Sciences Raichur during 2016-17. From each district 5 krishibhagya beneficiaries (including both Krishi Honda and Polyhouse) and 5 non beneficiaries were selected randomly following simple random sampling technique. The data was collected from the respondents using structured interview schedule prepared for the purpose.

The data collected includes details about the area of the farm and land use patterns, infrastructure and facilities on the farm, number of animals, cropping pattern before and after the scheme implementation, sources of irrigation, details about the financial aspects (cost of cultivation, returns, net income), constraints faced getting the benefit from the scheme, and suggestion for effective implementation of the schemes was sought.

The data collected was tabulated and analysed to draw valid conclusions. Simple statistical tools like simple averages, ratios, percentages and others were employed to analyze the data to draw meaningful inferences.

\section{Results and Discussion}

District wise and crop wise impact of Krishihonda (Farm pond) on yield and increase in income of beneficiary farmers

The data with respect to district wise and crop wise impact of Krishihonda (Farm pond) on yield and increase in income of beneficiary farmers is presented in Table 1. It is clear from 
the table 1 that, more than fifty per cent average increase in yield was observed in wheat (50.10) and Bengalgram (56.70) crops followed by soyabean (43.80) and Greengram (41.70). In Kalaburagi district an average increase in yield up to 52.00 per cent was observed in case of Redgram followed by dry chillies (34.10).

In Yadgir district, more than fifty per cent increase in yield was observed in crops like Bengalgram (62.50), Sunflower (60.00) and Groundnut (52.00). More than fifty percent increase in yield was observed in Redgram crop (55.60) in Raichur district followed by sunflower (48.80) and Bengalgram (38.90) crops. In Koppal district also, an average increase in yield of 51.50 per cent was observed in Sorghum followed by Cotton (43.10), Bengalgram (40.70), Maize and Dry chillies (25.00). In Ballari district an average of forty percent increase in yield was observed in crops like Sorghum and Groundnut followed by Cotton (30.70) and Sunflower (23.10).

\section{Impact of Krishihonda (Farm pond) on average increase in yield of important crops}

It is clear from the results presented in table 2 that, highest $(53.00 \%)$ average yield increase was observed in Redgram crop followed by Bengalgram (45.00\%), Sunflower (43.00\%), Sorghum (40.00\%), Wheat $(38.00 \%)$ and Groundnut $(36.00 \%)$. The reason that could be attributed to this phenomenon is availability of water, and additional storage of moisture in the soil profile leading to increased production and productivity.

The results are in line with the results obtained by Desai Rajeshwari et al., (2007) and Chavai et al., (2015).
Impact of Krishihonda (Farm pond) on average increase in income of beneficiary farmers

It is clear from the results presented in table 3 that, highest average increase in income of Rs. 43848 was observed in case of Cotton followed by Dry chillies (Rs. 39100), Paddy (Rs. 27825), Maize (Rs. 18342.50), Groundnut (Rs. 17290) and Wheat (Rs. 14898.33). The increase in average income of the beneficiary farmers might be attributed to the increase in the yield of the crops due to additional protective irrigation provided to the crops from the farm ponds.

Similar results of increase in total annual income due to farm ponds were also reported by Desai Rajeshwari et al., (2007) and Chavai et al., (2015). Munyaneza et al., (2016) also reported increase in level of living both economically and healthily after incorporation of RWH Ponds in the daily farming activities of the beneficiaries.

Impact of polyhouse/shade net on average increase in yield and income of beneficiaries in important horticulture crops

It is clear from the results presented in the table 4 that, an average increase in the yield of more than fifty percent was observed in case of crops like Cucumber (58.27 \%) and Brinjal (51.88 \%) followed by Capsicum (41.97\%) and Ladys Finger $(37.00 \%)$ grown in polyhouse/shade net. But in case of increase in average income, highest average income was observed in tomato crop (Rs. 75020) followed by Ladys Finger (Rs. 65520), Cucumber (Rs. 50340), Brinjal (Rs. 31660) and Capsicum (Rs. 31275). 
Table.1 District wise and crop wise impact of Krishihonda (Farm pond) on yield and increase in income of beneficiary farmers

\begin{tabular}{|c|c|c|c|c|c|c|c|c|}
\hline \multirow{2}{*}{$\begin{array}{l}\text { Sl. } \\
\text { No. }\end{array}$} & \multirow[t]{2}{*}{ District } & \multicolumn{3}{|c|}{ Non beneficiary farmers } & \multicolumn{2}{|c|}{ Beneficiary farmers } & \multirow{2}{*}{$\begin{array}{c}\% \\
\text { increase }\end{array}$} & \multirow{2}{*}{$\begin{array}{l}\text { Increase } \\
\text { in } \\
\text { income }\end{array}$} \\
\hline & & Crop & $\begin{array}{c}\text { Yield } \\
\text { (Qntl) }\end{array}$ & $\begin{array}{c}\text { Area } \\
\text { (Acre) }\end{array}$ & $\begin{array}{c}\text { No. Of } \\
\text { irrigations }\end{array}$ & $\begin{array}{c}\text { Yield } \\
\text { (Qntl) }\end{array}$ & & \\
\hline \multirow[t]{7}{*}{1} & \multirow[t]{7}{*}{ Bidar } & Greengram & 4.0 & 1 & 1 & 5.67 & 41.70 & 13200 \\
\hline & & Blackgram & 3.5 & 1 & 1 & 4.60 & 31.4 & 19360 \\
\hline & & Soyabean & 8.0 & 1 & 1 & 11.50 & 43.8 & 21000 \\
\hline & & Bengalgram & 3.0 & 1 & 1 & 4.70 & 56.7 & 12000 \\
\hline & & Wheat & 15.0 & 1 & 2 & 22.52 & 50.1 & 12320 \\
\hline & & Sugarcane & 700.0 & 1 & 4 & 846.00 & 20.9 & 59860 \\
\hline & & Sorghum & 2.5 & 1 & 1 & 3.17 & 26.7 & 3100 \\
\hline \multirow[t]{5}{*}{2} & \multirow[t]{5}{*}{ Kalaburagi } & Redgram & 6.0 & 1 & 1 & 9.12 & 52.0 & 13300 \\
\hline & & Cotton & 15.0 & 1 & 3 & 18.33 & 22.2 & 27000 \\
\hline & & Groundnut & 10.0 & 1 & 1 & 12.25 & 22.5 & 17100 \\
\hline & & Maize & 25.0 & 1 & 2 & 29.94 & 19.8 & 22910 \\
\hline & & Dry chillies & 25.0 & 1 & 3 & 33.53 & 34.1 & 15300 \\
\hline \multirow[t]{7}{*}{3} & \multirow[t]{7}{*}{ Yadgir } & Groundnut & 10.0 & 1 & 2 & 15.20 & 52.0 & 12160 \\
\hline & & Cotton & 18.0 & 1 & 3 & 23.75 & 31.9 & 37260 \\
\hline & & Dry chillies & 25.0 & 1 & 3 & 30.00 & 20.0 & 90000 \\
\hline & & Sunflower & 6.0 & 1 & 2 & 9.60 & 60.0 & 12600 \\
\hline & & Wheat & 13.5 & 1 & 2 & 20.00 & 48.1 & 16625 \\
\hline & & Bengalgram & 4.0 & 1 & 2 & 6.50 & 62.5 & 7500 \\
\hline & & Maize & 25.0 & 1 & 3 & 34.75 & 39.0 & 28275 \\
\hline \multirow[t]{5}{*}{4} & \multirow[t]{5}{*}{ Raichur } & Paddy & 30.0 & 1 & 3 & 35.60 & 18.7 & 29400 \\
\hline & & Cotton & 15.0 & 1 & 3 & 19.75 & 31.7 & 51300 \\
\hline & & Redgram & 7.5 & 1 & 1 & 11.67 & 55.60 & 11375 \\
\hline & & Bengalgram & 4.5 & 1 & 2 & 6.25 & 38.9 & 17500 \\
\hline & & Sunflower & 7.0 & 1 & 2 & 10.42 & 48.8 & 9300 \\
\hline \multirow[t]{8}{*}{5} & \multirow[t]{8}{*}{ Koppal } & Groundnut & 10.0 & 1 & 2 & 13.00 & 30.0 & 17100 \\
\hline & & $\begin{array}{l}\text { Sorghum } \\
\text { (Rabi) }\end{array}$ & 5.0 & 1 & 2 & 7.00 & 40.0 & 1860 \\
\hline & & Dry chillies & 24.0 & 1 & 3 & 30.00 & 25.0 & 12000 \\
\hline & & Wheat & 12.5 & 1 & 1 & 14.75 & 18.0 & 15750 \\
\hline & & Sorghum & 5.5 & 1 & 1 & 8.33 & 51.5 & 3487.5 \\
\hline & & Bengalgram & 4.5 & 1 & 1 & 6.33 & 40.7 & 5000 \\
\hline & & Cotton & 17.0 & 1 & 4 & 24.33 & 43.1 & 54000 \\
\hline & & Maize & 20.0 & 1 & 1 & 27.50 & 25.0 & 7975 \\
\hline \multirow[t]{8}{*}{6} & \multirow[t]{8}{*}{ Ballari } & Paddy & 32.0 & 1 & 5 & 37.00 & 15.6 & 26250 \\
\hline & & Cotton & 15.0 & 1 & 1 & 19.60 & 30.7 & 49680 \\
\hline & & Groundnut & 10.0 & 1 & 3 & 14.00 & 40.0 & 22800 \\
\hline & & Maize & 24.6 & 1 & 3 & 29.50 & 19.9 & 14210 \\
\hline & & Sunflower & 6.5 & 1 & 2 & 8.00 & 23.1 & 4500 \\
\hline & & Sugarcane & 75.0 & 1 & 4 & 92.00 & 22.7 & 149600 \\
\hline & & Bengalgram & 4.5 & 1 & 1 & 5.80 & 28.9 & 16250 \\
\hline & & Sorghum & 5.0 & 1 & 1 & 7.00 & 40.0 & 1550 \\
\hline
\end{tabular}


Table.2 Impact of Krishihonda (Farm pond) on average increase in yield of important crops

\begin{tabular}{|c|l|c|c|c|}
\hline $\begin{array}{c}\text { SL. } \\
\text { No. }\end{array}$ & \multicolumn{1}{|c|}{ Crop } & $\begin{array}{c}\text { Non beneficiary } \\
\text { farmers yield } \\
\text { (Qntl/acre) }\end{array}$ & $\begin{array}{c}\text { Beneficiary } \\
\text { farmers yield } \\
\text { (Qntl/acre) }\end{array}$ & $\begin{array}{c}\text { Average yield } \\
\text { increase (\%) }\end{array}$ \\
\hline $\mathbf{1}$ & Cotton & 16 & 21.12 & 31 \\
\hline $\mathbf{2}$ & Paddy & 31 & 36.3 & 17 \\
\hline $\mathbf{3}$ & Redgram & 6.75 & 10.39 & 53 \\
\hline $\mathbf{4}$ & Sorghum & 4.5 & 6.37 & 40 \\
\hline $\mathbf{5}$ & Bengalgram & 4.1 & 5.91 & 45 \\
\hline $\mathbf{6}$ & Wheat & 13.66 & 19.09 & 38 \\
\hline $\mathbf{7}$ & Groundnut & 10 & 13.61 & 36 \\
\hline $\mathbf{8}$ & Dry chillies & 24.66 & 31.17 & 26 \\
\hline $\mathbf{9}$ & Sunflower & 6.5 & 9.34 & 43 \\
\hline $\mathbf{1 0}$ & Maize & 23.65 & 30.42 & 25 \\
\hline
\end{tabular}

Table.3 Impact of Krishihonda (Farm pond) on average increase in income of beneficiary farmers

\begin{tabular}{|c|l|c|}
\hline SL. No. & \multicolumn{1}{|c|}{ Crop } & Increase in income (Rs.) \\
\hline $\mathbf{1}$ & Cotton & 43848 \\
\hline $\mathbf{2}$ & Paddy & 27825 \\
\hline $\mathbf{3}$ & Redgram & 12337.5 \\
\hline $\mathbf{4}$ & Sorghum & 2499.37 \\
\hline $\mathbf{5}$ & Bengalgram & 11650 \\
\hline $\mathbf{6}$ & Wheat & 14898.33 \\
\hline $\mathbf{7}$ & Groundnut & 17290 \\
\hline $\mathbf{8}$ & Dry chillies & 39100 \\
\hline $\mathbf{9}$ & Sunflower & 8800 \\
\hline $\mathbf{1 0}$ & Maize & 18342.5 \\
\hline
\end{tabular}

Table.4 Impact of polyhouse/shade net on average increase in yield of important horticulture crops

\begin{tabular}{|l|l|l|l|l|l|}
\hline $\begin{array}{l}\text { SL. } \\
\text { No. }\end{array}$ & Crop & $\begin{array}{l}\text { Non } \\
\text { beneficiary } \\
\text { farmers yield } \\
\text { (Qntl/acre) }\end{array}$ & $\begin{array}{l}\text { Beneficiary } \\
\text { farmers yield } \\
\text { (Qntl/acre) }\end{array}$ & $\begin{array}{l}\text { Average yield } \\
\text { increase (\%) }\end{array}$ & $\begin{array}{l}\text { Increase in } \\
\text { income } \\
\text { (Rs.) }\end{array}$ \\
\hline $\mathbf{1}$ & Tomato & 242 & 317.02 & 31.07 & 75020 \\
\hline $\mathbf{2}$ & Cucumber & 108 & 170.925 & 58.27 & 50340 \\
\hline $\mathbf{3}$ & Capsicum & 41.375 & 58.75 & 41.97 & 31275 \\
\hline $\mathbf{4}$ & Ladys Finger & 220 & 301.9 & 37.00 & 65520 \\
\hline $\mathbf{5}$ & Brinjal & 121.8 & 185.12 & 51.88 & 31660 \\
\hline
\end{tabular}


The increase in average yield and income of the beneficiary farmers might be attributed to the fact that, the crops are cultivated in the protected environment where utmost care is taken due to which pest and disease infestation is very low along with the life saving irrigation provided to the crops.

It is clearly concluded from the results of the study that, there is a 17 to 53 per cent increase in average yield of important crops due to implementation of Krishihonda (Farm pond)under Krishibhagya scheme and increase in income of the beneficiary farmers.

There is a 31 to 58 per cent increase in yield of important horticulture crops due to polyhouse/shade net under Krishibhagya scheme. Hence there is a need to continue and implement the krishibhagya scheme to other areas. There is a need to educate the farmers to go for cultivation of high value commercial crops instead of low value crops as the irrigation facility is available.

Administrators and policy makers should

\section{How to cite this article:}

Moulasab, S.K. Meti, and Ashoka, M.B. 2018. Krishibhagya Scheme: An Impact Study for Improvement of Livelihood of the Farmers in Hyderabad-Karnataka Region, India. Int.J.Curr.Microbiol.App.Sci. 7(07): 565-570. doi: https://doi.org/10.20546/ijcmas.2018.707.069 think of adding more components to the scheme in order to improve the socioeconomic status of the farmers and for sustainable agriculture development.

\section{References}

Chavai, A. M., Rakshe, U. V. and Shinde, S. B., 2015, Impact of farm pond on the beneficiary farmers in Maharashtra. International Journal of Tropical Agriculture, 33(4): 3525- 3528.

Desai Rajeshwari, B.L. Patil, L.B. Kunnal, H. Jayashree and H. Basavaraj, 2007, Impact assessment of farm ponds in Dharwad district of Karnataka. Karnataka J. Agric.Sci. 20(2):426427.

Munyaneza, O., Majoro, F., Hagenimana, E. and Usabyisa, W., 2016, Impact Assessment of Hillside Rainwater Harvesting Ponds on Agriculture Income: Case Study of Ntarama Sector in Rwanda. Journal of Water Resource and Protection, 8, 844-854. 